\title{
Quantitative Proteomics Analysis of Maternal Plasma in Down Syndrome Pregnancies Using Isobaric Tagging Reagent (iTRAQ)
}

\author{
Varaprasad Kolla, ${ }^{1}$ Paul Jenö, ${ }^{2}$ Suzette Moes, ${ }^{2}$ Sevgi Tercanli, ${ }^{1}$ Olav Lapaire, ${ }^{1}$ \\ Mahesh Choolani, ${ }^{3}$ and Sinuhe Hahn ${ }^{1,3}$ \\ ${ }^{1}$ Department of Biomedicine, University Women's Hospital, 4031 Basel, Switzerland \\ ${ }^{2}$ Mass Spectrometry, Biozentrum, University of Basel, Klingelbergstrasse 50/70, 4056 Basel, Switzerland \\ ${ }^{3}$ Biomarker Discovery Laboratory, Department of Obstetrics and Gynecology, National University of Singapore, Singapore 19077
}

Correspondence should be addressed to Sinuhe Hahn, shahn@uhbs.ch

Received 3 July 2009; Accepted 21 August 2009

Academic Editor: Benjamin A. Garcia

Copyright (C) 2010 Varaprasad Kolla et al. This is an open access article distributed under the Creative Commons Attribution License, which permits unrestricted use, distribution, and reproduction in any medium, provided the original work is properly cited.

\begin{abstract}
Currently no specific biomarkers exist for the screening of pregnancies at risk for down syndrome (DS). Since a quantitative proteomic approach with isobaric labelling (iTRAQ) has recently been suggested to be highly suitable for the discovery of novel plasma biomarkers, we have now used this method to examine for potential quantitative changes in the plasma proteome of the pregnancies bearing DS fetuses in comparison to normal healthy babies. In our study, we used plasma from six women with DS pregnancies and six with uncomplicated pregnancies care were taken to match cases and controls for gestational and maternal age, as these could be a confounder. In our quantitative proteomics analysis we were able to detect 178 proteins using iTRAQ labelling in conjunction with 4800 MALDI TOF/TOF. Amongst these we observed changes in $\beta$ HCG, a known screening marker for DS, indicating that our assay was functional. We found a number of elevated proteins Ig lambda chain $\mathrm{C}$ region, serum amyloid Pcomponent, amyloid beta A4, and under expressed proteins like gamma-actin and titin in DS pregnancies. These proteins are also found in the sera of patients with Alzheimer disease, which share similar pathologies of DS. Our study therefore indicates that the iTRAQ labelling approach may be indeed useful for the detection of novel biomarkers.
\end{abstract}

\section{Introduction}

Down syndrome (DS) is the most common chromosomal aneuploidy in live births and a leading cause of mental retardation. Prenatal detection of chromosomal anomalies, such as trisomy 21 , in cases with DS relies on invasive practices such as amniocentesis or chorionic villi sampling. These procedures are associated with a risk of fetal loss or adverse pregnancy outcome [1]. Furthermore, it requires special facilities and highly trained staff. For this reason alternative strategies are sought, such as the noninvasive prenatal diagnosis of fetal genetic anomalies via the analysis of rare trafficking fetal cells [2] or cell-free fetal nucleic acids in maternal blood [3]. As this long sought goal has not yet reached clinical implementation [4], current clinical practice relies on a series of screening steps aimed at detecting atrisk pregnancies. In many centres the screening procedure for
DS is carried out in the late first and early second trimester (11-14 weeks of gestation) and involves a combination of ultrasound and serum marker analysis [5]. Although the efficacy of this method has improved considerably, and is more accurate than previous second trimester screening approaches, it is hampered by the skill and precision of the ultrasonographer and external factors such as ethnicity or other factors, such as assisted reproductive technologies.

Hence, it is obvious that new tools are needed to improve current state of the art. One such strategy is to look for new potential biomarkers using noninvasive proteomic approaches. The rationale for this strategy is that placentae from fetuses with DS, especially the villi, are morphologically distinct from the placentae of euploid fetuses, a feature attributed to altered aberrant protein expression [6]. As the placenta, a large organ with rapid cell turn-over is in direct contact with the maternal circulation, proteins 
TABle 1: Patients with and without a down syndrome pregnancy at the time of screening $n=6$.

\begin{tabular}{lcc}
\hline & \multicolumn{2}{c}{ First trimester } \\
\hline Maternal age (years) & $35.8 \pm 4.3$ & Control \\
Gestational age (weeks) & $12.4 \pm 1.2$ & $35.1 \pm 4.1$ \\
\hline
\end{tabular}

released by it should be detectable in maternal plasma, and could consequently serve as promising markers for abnormal placentation involved in a number of pregnancy related disorders. In this regard, preliminary proteomic investigations have shown that quantitative alterations in protein expression are found to occur in the amniotic fluid $[7,8]$ and maternal serum of pregnancies with fetuses affected with down syndrome, and that these could serve as new potential biomarkers [9].

Unfortunately none of these studies used quantitative approaches of the type that permit precise assessment of the extent of up- or down-regulation of the proposed biomarkers. As such, it will be difficult to validate these in blinded studies of clinical serum or plasma samples, a crucial facet in determining their specificity [9-11].

These studies are further complicated by the complex nature of the plasma/serum proteome, whereby the majority of low abundance proteins are masked by the preponderance of a few highly abundant proteins. This high dynamic range [12] effectively precludes the use of more conventional proteomic strategies, such as those employing gel electrophoresis with or without or fluorescent labelling, for example, Difference Gel Electrophoresis (DIGE). This deficit renders the identification of potential biomarkers in plasma/serum by conventional comparative proteomic approaches very challenging.

For this reason an approach using Isobaric Tags for Absolute and Relative Quantitation (iTRAQ) has been proposed for the discovery of plasma biomarkers [13]. This chemical labelling method involves the stable incorporation of isotopes into an amine tagging reagent, which can be reliably detected by mass spectrometry, thereby permitting comparative quantitation in a multiplex manner. Currently 4-plex and 8-plex reagents are commercially available, which are used to label the protein samples of interest following trypsin digestion. The use of different isobaric tags implies that up to 4 or 8 different samples, one of which serves as a reference, can be examined simultaneously in a single mass spectrometric analysis. It is for this reason that the iTRAQ approach has been suggested to be suitable for the discovery of biomarkers in a wide range of body fluids and tissues, including plasma.

In order to examine whether this approach would be suitable for the detection of potential biomarkers for down syndrome, we performed a proof-of-principle experiment, in which we examined samples from 6 cases with down syndrome in comparison to 6 matching controls. In our study we have used a 4-plex iTRAQ labelling in conjunction with a 4800 MALDI TOF/TOF approach to examine plasma samples obtained in first trimester pregnancies. Our results indicate that quantitative differences can be detected between aneuploid samples and samples from euploid pregnancies and that such alteration may reflect upon changes known to occur in down syndrome.

\section{Materials and Methods}

2.1. Samples. Blood samples for this case-control proteome study were collected from six pregnant women carrying a DS fetus (11-13 weeks of gestation) and six pregnant women with normal euploid pregnancies. The samples were matched for maternal and gestational age (Table 1). This study was undertaken with the approval of the Institutional Ethical Board of the University Hospital, Basel, Switzerland and written informed consent was required in all instances.

2.2. Sample Preparation. $9 \mathrm{~mL}$ blood was drawn into $\mathrm{BD}$ P100 tubes (BD Diagnostics, Franklin Lake, NY, USA), which are specially designed for proteomics experiments, in that the Ethylenediaminetetraacetic acid (EDTA) and protease inhibitor present in the tube prevent coagulation and stabilize the plasma proteome. Following phlebotomy the samples were centrifuged at $3000 \times \mathrm{g}$ for 30 minutes at $10^{\circ} \mathrm{C}$, whereby the plasma was separated from the cellular fraction by aid of a mechanical separator. $100 \mu \mathrm{L}$ aliquots were stored at $-80^{\circ} \mathrm{C}$ until further use. For an overview of the work-flow used in this analysis refer to Figure 1.

\subsection{Immunodepletion of High-Abundance Plasma Proteins. Highly abundant plasma proteins were depleted using Pro- teoMiner Protein Enrichment Kit (Bio-Rad Laboratories, Inc.) [14], as per the manufacturer's instructions. $1 \mathrm{~mL}$ of plasma was used for the depletion and after the whole procedure, $300 \mu \mathrm{L}$ was eluted in elution reagent. After depletion protein concentration was measured by using RC- DC Protein assay kit (Bio-Rad Laboratories, Inc.)}

2.4. Trypic Digestion and iTRAQ Reagent Labelling. Equal amounts $(100 \mu \mathrm{g})$ of depleted plasma protein from six of the DS cases and controls were pooled separately in duplicate for the iTRAQ labelling. These samples were denatured with $2 \%$ SDS in $500 \mathrm{mM}$ triethylammonium bicarbonate (TEAB) (Sigma-Aldrich) for 15 minutes at room temperature, following which they were reduced with $2 \mu L$ of $50 \mathrm{mM}$ tri-(2-carboxyethyl) phosphine (TCEP) (SigmaAldrich) at $60^{\circ} \mathrm{C}$ for 1 hour and were then alkylated with $10 \mathrm{mM} \mathrm{s}$-Methylmethanethisulfonate (MMTS) for 10 minutes in room temperature. After alkylation, the proteins were digested overnight at $37^{\circ} \mathrm{C}$ with $1 \mathrm{U} / \mu L$ trypsin (TPCK treated) (Applied Biosystems, Foster City, CA 94404, USA). Peptides were labelled with one unit of iTRAQ Reagent Multi-plex kit (Applied Biosystems, Foster City, CA 94404, USA) that was reconstituted in $70 \mu \mathrm{L}$ of ethanol. iTRAQ labels 114,116 were used separately for labelling the pooled duplicated control sample and 115, 117 were used separately to label the pooled duplicate down syndrome samples. The iTRAQ labelling reagent solution was added to the digest and incubated for 1 hour at room temperature. To assess the 


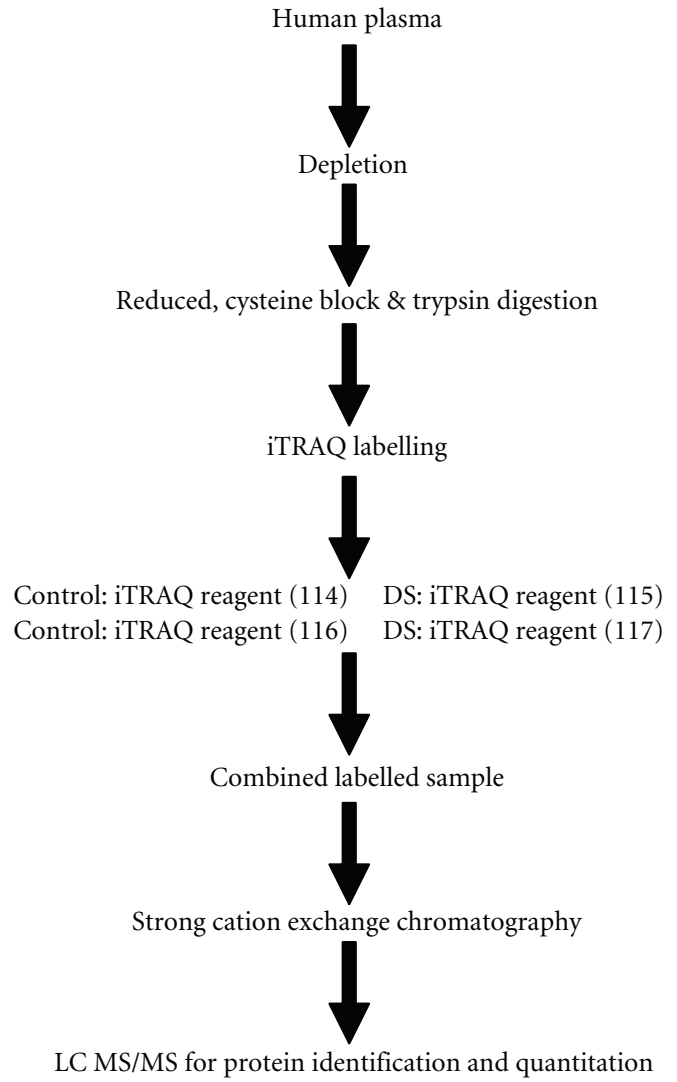

Figure 1: Workflow for quantitative proteomics using iTRAQ reagent. Equal amounts of plasma protein $(100 \mu \mathrm{g})$ from control and DS $(n=6)$ were pooled separately and duplicated, controls were labeled with 114 and 116 iTRAQ label and DS was labeled with 115 and 117 iTRAQ label. The labeled samples were pooled and were subjected to a strong cation exchange chromatography to remove the excess label. Afterwards LC-MALDI MS/MS was performed for protein identification and quantification.

accuracy of the ratiometric quantitation of ITRAQ reagent a split in signal was performed and the data were corrected as described in detail by Unwin and colleague [15].

2.5. Strong Cation Exchange Chromatography (SCX). Strong cation exchange chromatography was preformed to remove the excess iTRAQ reagent and interfering substances for the mass analysis. Dried peptides were resuspended in $200 \mu \mathrm{L}$ of Buffer A and were loaded on Poly Sulfoethyl A Column (200 mm length $\times 4.6$ id, $5 \mu \mathrm{m}$ particle size, 200 pore size) on a BioLC HPLC unit (Dionex). Buffer A consisted of $10 \mathrm{mM}$ $\mathrm{KHPO}_{4}$ and $25 \%$ acetonitrile, $500 \mathrm{mM} \mathrm{KCl}, \mathrm{pH} 3.0$, and Buffer B consisted of $10 \mathrm{mM} \mathrm{KH}_{2} \mathrm{PO}_{4}, 25 \%$ acetonitrile, and $500 \mathrm{mM} \mathrm{KCl} \mathrm{pH} \mathrm{3.0.} \mathrm{The} 60$ minutes gradient comprised of $100 \%$ Buffer A for 5 minutes, $5 \%-30 \%$ Buffer B for 40 minutes, 30\%-100\% Buffer B for 5 minutes, $100 \%$ Buffer B for 5 minutes, and finally 100\% Buffer A for 5 minutes. Ten fractions were collected using a Foxy Jr. Fraction Collector (Dionex). Subsequently, these fractions were pooled according to the chromatogram profile based on the peak intensity and the products dried in a vacuum concentrator, after which they were stored at $-20^{\circ} \mathrm{C}$ prior to mass spectrometric analysis.

2.6. Nano LC MALDI. The dried SCX iTRAQ-labeled peptides were dissolved in Buffer A which consist of $95 \% \mathrm{H}_{2} \mathrm{O}$, $5 \%$ acetonitrile, $0.1 \%$ TFA and were loaded on $\mathrm{C} 18$ trap column $(1 \mathrm{~mm} \times 300 \mu \mathrm{m}$ i.d. column $)$ at $30 \mu \mathrm{L} /$ minutes and separated on an analytical column $(150 \mathrm{~mm} \times 100 \mu \mathrm{m}$ i.d. column) at $500 \mathrm{~nL} / \mathrm{min}$ using the LC-packing Ultimate system. The peptides were separated using a linearly increasing concentration of acetonitrile in Buffer B from $5 \%$ to $30 \%$ in 120 minutes, and from $30 \%$ to $60 \%$ in 40 minutes. The elute was mixed with matrix $(2 \mathrm{mg} / \mathrm{mL}$ alpha-cyano-4hydroxycinnamic acid in $80 \%$ acetonitrile, and $0.1 \%$ TFA) at a flow rate of $800 \mathrm{nl} / \mathrm{min}$ and deposited on an OptiTOF LC/MALDI (Applied Biosystems) plate in $10 \mathrm{~S}$ fractions, using an automatic robot (Probot, Dionex).

2.7. MS and MSMS. The Mass spectrometer 4800 plus MALDI TOF/TOF Analyzer (Applied Biosystems) was set to perform data acquisition in positive ion mode. An MS condition of 1000 shots per spectrum was used. Monoisotopic precursor selection for MS/MS was done by automatic precursor selection using an interpretation method using the 12 most intense peaks per spot with an MS/MS mode condition of 4000 laser shots per spectrum. Minimum peak width was one fraction and mass tolerance was $80 \mathrm{ppm}$. Adduct tolerance is $(\mathrm{m} / \mathrm{z}) \pm 0.003$. MSMS was done with a gas pressure of $2 \times 10^{-2}$ bar in the collision cell. Air was used as collision gas.

2.8. Protein Identification and Database Searches. Protein identification and quantification was done by using the ProteinPiolt software v2.0 (Applied Biosystems; MDS-Sciex). The search was performed against the Human database of UniProtKB/Swiss-Prot (Version 3.50) from the EBI website (http://www.ebi.ac.uk./IPI/IPIhelp.html) and concatenated target-decoy database search strategy was used to check the false positive rate [16] in our case it was found to be $0 \%$, which boosted the reliability of our data.

2.9. Relative Quantitation Criteria. The Paragon algorithm $[17,18]$ in ProteinPiolt v2.0 software was used as the default search program with digestion enzyme set as trypsin and methyl methanethiosulfonate as cysteine modification. The search also included the possibility of more than eighty biological modifications and amino acid substitution of up to two substitutions per peptide using the BLOSUM 62 matrix. Data were normalized for loading error by bias correction calculated with Progroup algorithm Identified proteins with at least $95 \%$ confidence and with a ProtScore of 1.3 , were reported. The results obtained from ProteinPiolt software v2.0 software were exported to Microsoft Excel for the further analysis. The study was performed in double duplex manner, where DS samples were labelled with 115 and 117, control were labelled with 114 and 116. Peptides were selected based on the criteria defined in the protein pilot software, which means all the peptides were included for quantitation with 
an exception for those without an iTRAQ modification or reporter ion, an area count less than 40 and peptides with $P$ value less than .001 were excluded [19]. As described by Gan and colleague in their study on estimation of relative quantitative ratio from iTRAQ experiments, we also used only peptides above or equal to $70 \%$ confidence level for the estimation of relative quantitation [20].

2.10. PANTHER Analysis. The PANTHER database was used to elucidate the molecular function, biological process and signaling pathway associated with each individual protein (http://panther.appliedbiosystems.com/).

\section{Results}

Samples were obtained from 6 cases with a confirmed DS fetus and 6 samples from normal euploid singleton pregnancies. Care was taken to match both maternal and gestational age, to rule out any confounding influence of these two parameters.

Low abundant plasma proteins were enriched by using ProteoMiner Protein Enrichment Kit. This was accomplished through the use of a large, highly diverse bead-based library of combinatorial peptide ligands. When plasma was applied to the beads, a small fraction of the high abundance proteins saturated their high affinity ligands and the excess high abundance proteins were washed away. In addition a very small amount of high abundance proteins and low abundance proteins were concentrated on their specific affinity ligands. This provides for a significant enrichment of medium and low abundant plasma proteins.

The samples were pooled separately in and duplicate in order to have more precise analytical replicate measurements. The iTRAQ analysis was done in double duplex style, the DS samples were labelled with iTRAQ 115 and 117 and the control samples with iTRAQ 114 and 116, using the work-flow illustrated in Figure 1.

Following tandem MS MS, and by focussing on iTRAQ reporter ions in low molecular mass range $(114-117 \mathrm{Da})$ for quantification, we identified 235 proteins with $\geq 95 \%$ confidence. However, after manually rechecking the MS/MS data thoroughly peak by peak, only 187 out of 235 proteins $(78.5 \%)$ had a relative quantitation derived from the analysis of two or more peptides, while for 45 proteins, the quantitation was based on single peptide. For 3 proteins no quantitation could be ascertained by analysis using Protein Pilot. Figure 2 shows the MSMS spectrum of the precursor $([\mathrm{M}+\mathrm{H}]+, m / z$ 1527.7 Da). In low-mass region the reporter ions, are seen while area under the curve was used for quantification.

As we did the experiment in double duplex manner, DS (115 and 117) and control (114 and 116), it was possible to estimate the cutoff point for differentially expressed protein in our sample $[19,20]$. Based on 187 relative abundant protein ratios from DS and control sample, an average variation of $4.4 \%( \pm 0.04)$ was measured. If the cutoff was set at $5 \%$ average variance then only $72 \%$ of the proteins would fall with in this variation range, but. If the range was
MSMS 1527.7 Da HQDGSYSTFGER

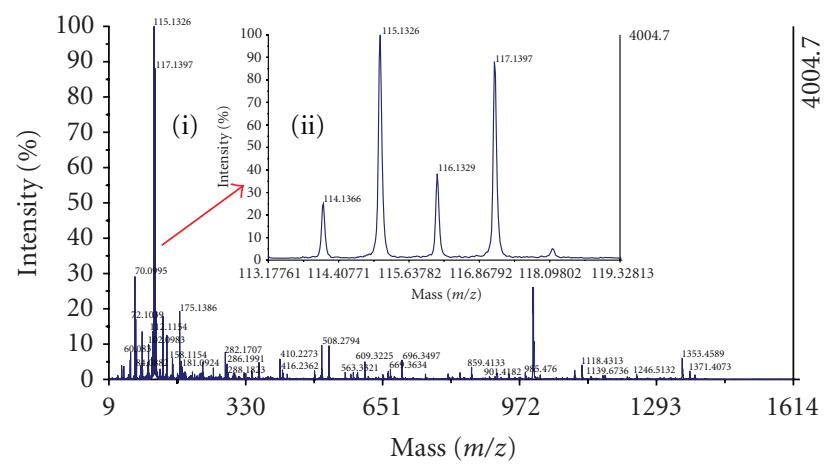

FIGURE 2: Components of the spectrum illustrated are (i) MSMS spectrum of the precursor $([\mathrm{M}+\mathrm{H}]+, m / z 1527.7 \mathrm{Da})$. (ii) lowmass region showing the reporter ions used for quantitation. The peptide is labeled by isobaric tags at both the $\mathrm{N}$ terminus and $\mathrm{C}$ terminal lysine side chain. The precursor ion and all the fragment ions therefore contain all four members of the tag set, but remain isobaric. The MSMS spectrum was obtained from the singly charged $[\mathrm{M}+\mathrm{H}]+$ peptide using a 4800 MALDI TOF-TOF analyzer.

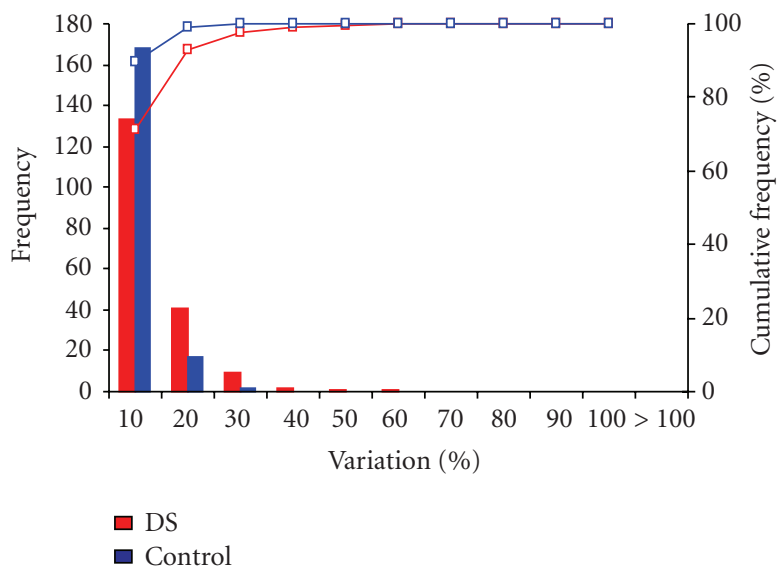

FIGURE 3: Frequency distribution (bars) from both DS and control replicates across different ranges of variation. The cumulative percentage (lines) is defined as the cumulative number of proteins falling within the defined variation range against the total number of protein.

increased to $20 \%$ then about $92 \%$ of the protein falls in this variation range as illustrated in Figure 3. So the cutoff point in this experiment was set at $20 \%( \pm 0.2)$. That means any relative change in protein ratio below or above \pm 1.2 fold was considered as differentially under or over expressed.

The functional distribution of these proteins is illustrated in Figure 4. For this interpretation, an analysis of 235 proteins was performed using the PANTHER classification system, which sorts the proteins into respective classes based on their biological process.

It is of interest that two of the major groups involve cell adhesion molecules (13\%) and extra cellular matrix proteins (18\%) and member of the protease family, factors that are known to be aberrant in down syndrome. Further more large 
TABLE 2: List of the protein identified as up-regulated from the iTRAQ experiment, indicating is the biological process and molecular function of these proteins. ( $P$ value. 001).

\begin{tabular}{|c|c|c|c|c|c|}
\hline No. & Acc. number & $\% \operatorname{Cov}$ & Protein name & Biological processes & Molecular functions \\
\hline 1 & P20742 & 31.5 & Pregnancy zone protein & $\begin{array}{l}\text { Ligand-mediated } \\
\text { signaling }\end{array}$ & Other cytokine \\
\hline 2 & P04003 & 30 & $\begin{array}{l}\text { C4b-binding protein } \\
\text { alpha chain }\end{array}$ & $\begin{array}{l}\text { Complement- } \\
\text { mediated } \\
\text { immunity }\end{array}$ & $\begin{array}{l}\text { Complement } \\
\text { component }\end{array}$ \\
\hline 3 & P01842 & 68.6 & $\begin{array}{l}\text { Ig lambda chain C } \\
\text { regions }\end{array}$ & Immunity & Immunoglobulin \\
\hline 4 & P01233 & 26.1 & $\begin{array}{l}\text { Choriogonadotropin } \\
\text { subunit beta }\end{array}$ & mRNA transcription & $\begin{array}{l}\text { Other signaling } \\
\text { molecule }\end{array}$ \\
\hline 5 & P43251 & 14.1 & Biotinidase & Vitamin metabolism & Other hydrolase \\
\hline 6 & P01834 & 84 & $\begin{array}{l}\text { Ig kappa chain C } \\
\text { region }\end{array}$ & Immunity & Immunoglobulin \\
\hline 7 & P01859 & 42 & $\begin{array}{l}\text { Ig gamma-2 chain } \mathrm{C} \\
\text { region }\end{array}$ & Immunity & Immunoglobulin \\
\hline 8 & P01215 & 6 & $\begin{array}{l}\text { Glycoprotein } \\
\text { hormones alpha chain }\end{array}$ & $\begin{array}{l}\text { Protein targeting } \\
\text { and localization }\end{array}$ & SNARE protein \\
\hline 9 & P80108 & 16.5 & $\begin{array}{l}\text { Phosphatidylinositol- } \\
\text { glycan }\end{array}$ & $\begin{array}{l}\text { Intracellular } \\
\text { signaling cascade }\end{array}$ & Lipase \\
\hline 10 & P01860 & 53.8 & $\begin{array}{l}\text { Ig gamma-3 chain } \mathrm{C} \\
\text { region }\end{array}$ & $\begin{array}{l}\text { B-cell- and } \\
\text { antibody-mediated } \\
\text { immunity }\end{array}$ & Immunoglobulin \\
\hline 11 & Q9UGM5 & 27.5 & Fetuin-B & $\begin{array}{l}\text { Intracellular } \\
\text { signaling cascade }\end{array}$ & Lipase \\
\hline 12 & P35858 & 26 & $\begin{array}{l}\text { Insulin-like growth } \\
\text { factor }\end{array}$ & Cell adhesion & Receptor \\
\hline 13 & P26927 & 22.9 & $\begin{array}{l}\text { Hepatocyte growth } \\
\text { factor-like protein }\end{array}$ & $\begin{array}{l}\text { Ligand-mediated } \\
\text { signaling }\end{array}$ & Growth factor \\
\hline 14 & P02751 & 49.4 & Fibronectin & $\begin{array}{l}\text { Extracellular matrix } \\
\text { protein }\end{array}$ & $\begin{array}{l}\text { Cell adhesion } \\
\text { molecule }\end{array}$ \\
\hline 15 & P02743 & 54.3 & $\begin{array}{l}\text { Serum amyloid } \\
\text { P-component }\end{array}$ & $\begin{array}{l}\text { Amino acid } \\
\text { biosynthesis }\end{array}$ & Synthase \\
\hline 16 & P00751 & 37.7 & Complement factor B & Proteolysis & Serine protease \\
\hline 17 & P01031 & 42.6 & Complement C5 & $\begin{array}{l}\text { Complement- } \\
\text { mediated } \\
\text { immunity }\end{array}$ & $\begin{array}{l}\text { Complement } \\
\text { component }\end{array}$ \\
\hline 18 & P07358 & 36.5 & $\begin{array}{l}\text { Complement } \\
\text { component } \mathrm{C} 8 \text { beta } \\
\text { chain }\end{array}$ & $\begin{array}{l}\text { Complement- } \\
\text { mediated } \\
\text { immunity }\end{array}$ & $\begin{array}{l}\text { Complement } \\
\text { component }\end{array}$ \\
\hline 19 & P02790 & 67.3 & Hemopexin & $\begin{array}{l}\text { Vitamin/cofactor } \\
\text { transport }\end{array}$ & Carrier protein \\
\hline 20 & P00734 & 61.3 & Prothrombin & Blood clotting & Serine protease \\
\hline 21 & Q14624 & 54.8 & $\begin{array}{l}\text { Inter-alpha-trypsin } \\
\text { inhibitor heavy chain } \\
\text { H4 }\end{array}$ & Proteolysis & $\begin{array}{l}\text { Serine protease } \\
\text { inhibitor }\end{array}$ \\
\hline 22 & O00213 & 10.8 & Amyloid beta A4 & $\begin{array}{l}\text { Other neuronal } \\
\text { activity }\end{array}$ & $\begin{array}{l}\text { Other signaling } \\
\text { molecule }\end{array}$ \\
\hline 23 & P08603 & 61.7 & Complement factor $\mathrm{H}$ & $\begin{array}{l}\text { Complement- } \\
\text { mediated } \\
\text { immunity }\end{array}$ & $\begin{array}{l}\text { Complement } \\
\text { component }\end{array}$ \\
\hline 24 & P00738 & 53 & Haptoglobin & $\begin{array}{l}\text { Neurotransmitter } \\
\text { release }\end{array}$ & Vesicle coat protein \\
\hline
\end{tabular}


Table 2: Continued.

\begin{tabular}{|c|c|c|c|c|c|}
\hline No. & Acc. Number & $\% \mathrm{Cov}$ & Protein name & Biological processes & Molecular functions \\
\hline 25 & P22891 & 10.3 & $\begin{array}{l}\text { Vitamin K-dependent } \\
\text { protein } \mathrm{Z}\end{array}$ & Proteolysis & Serine protease \\
\hline 26 & P22792 & 14.1 & $\begin{array}{l}\text { Carboxypeptidase } \mathrm{N} \\
\text { subunit } 2\end{array}$ & Cell surface receptor & Receptor \\
\hline 27 & P07357 & 27.9 & $\begin{array}{l}\text { Complement } \\
\text { component C8 }\end{array}$ & $\begin{array}{l}\text { Complement- } \\
\text { mediated } \\
\text { immunity }\end{array}$ & $\begin{array}{l}\text { Complement } \\
\text { component }\end{array}$ \\
\hline 28 & P02741 & 8.9 & C-reactive protein & Stress response & $\begin{array}{l}\text { Defense and } \\
\text { immunity }\end{array}$ \\
\hline
\end{tabular}

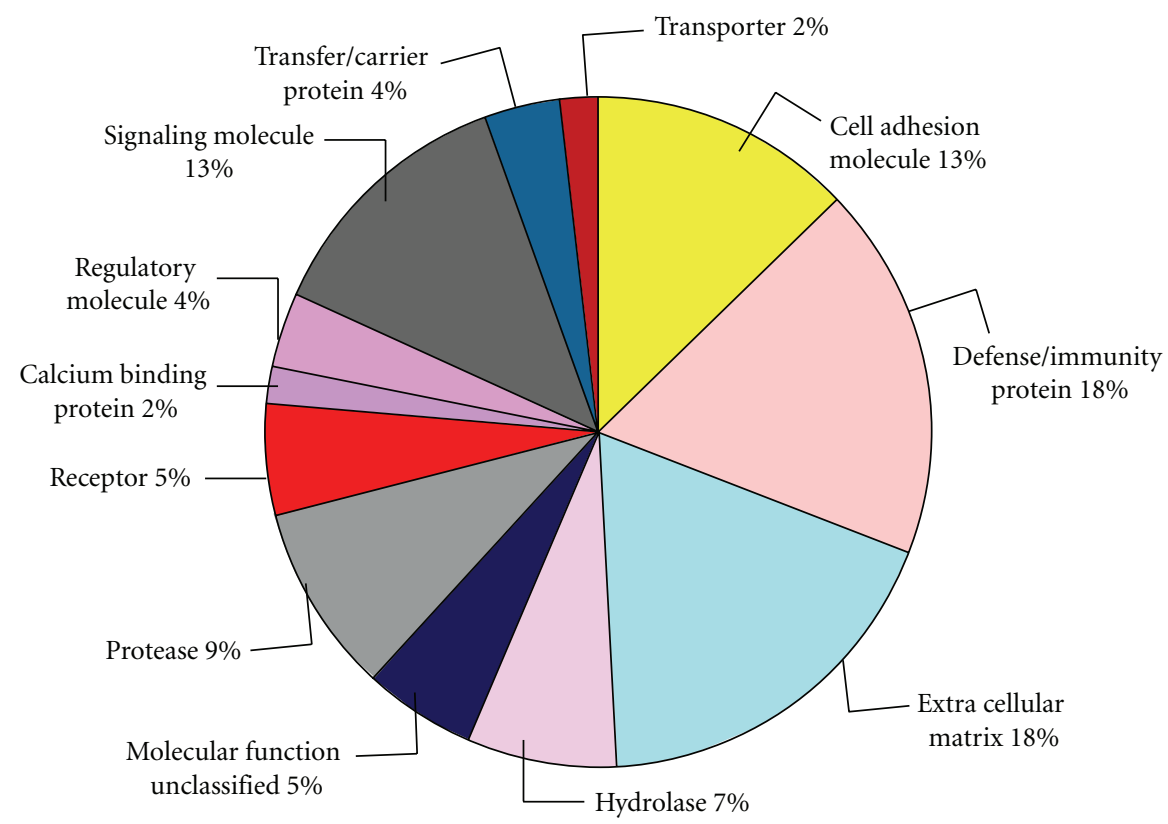

FIGURE 4: Number of plasma protein identified using iTRAQ reagent. In total, 235 proteins were identified. Shown above is the classification of these protein in different category based on molecular function.

groups were found to involve signalling molecules (13\%) and $18 \%$ defense/immunity proteins.

Of the large group of significantly up-regulated proteins, it is highly noteworthy that this includes $\beta \mathrm{HCG}$ (Beta human chorionic gonadotropin), a subunit of the human chorionic gonadotropin protein known to be elevated in pregnancies [5] with DS fetuses, and which forms one of the backbone of current screening programs in the first trimester. This finding, therefore strongly suggests, that the iTRAQ method we have chosen appears to be able to identify relevant proteins (Table 2 ). In this group, elevations were also recorded for pregnancy zone protein (PZP) (P20742), thereby indicating that our assay is indeed detecting proteins of placental origin. Elevation of two members of the amyloid family (Serum amyloid P-component and Amyloid beta A4) was also observed, which could be a significant finding, as these proteins have been suggested to play a role in the dementia found to occur in adult DS patients. An elevation in the inflammatory response marker, C-reactive protein and members of the immunoglobulin family like Ig lambda chain $\mathrm{C}$ region was also noted, which could be indicative of an increased inflammatory response in DS pregnancies. phosphatidylinositol-glycan (P80108), Insulin-like growth factor (P35858) is involved in protein-protein interactions that result in protein complexes and hepatocyte growth factor (P26927) was also prominent amongst the list of the up-regulated proteins.

Amongst the group of down-regulated proteins (Table 3) were a number of molecules involved in cell adhesion and extracellular matrix including titin (Q8WZ42), basement membrane specific heparan sulfate proteoglycan (P98160), actin, cytoplasmic 2 (Gamma-actin) (P63261)and fibrinogen alpha chain (P02671). This observation could be important as changes in tissue elasticity are a hallmark of DS cases, and play significant role in their detection by ultrasound via the presence of an increased neck fold (nuchal translucency). peroxiredoxin 2 (PRDX2), an antioxidant enzyme, is underexpressed in DS fetal brain and dynein heavy chain 9, was also noted in our list of down regulated proteins.

The PANTHER database was used for the pathway analysis on the proteins which were shown to be over or under expressed in our study. It was interesting to note that 
TABLE 3: List of the protein identified as down regulated from the iTRAQ experiment, indicating is the biological process and molecular function of these proteins. ( $P$ value .001$)$.

\begin{tabular}{|c|c|c|c|c|c|}
\hline No. & Acc. number & $\% \operatorname{Cov}$ & Protein name & Biological processes & Molecular functions \\
\hline 1 & P01009 & 32.8 & Alpha-1-antitrypsin & $\begin{array}{l}\text { Nerve-nerve } \\
\text { synaptic } \\
\text { transmission }\end{array}$ & Glutamate receptor \\
\hline 2 & P02768 & 67 & Serum albumin & $\begin{array}{l}\text { Amino acid } \\
\text { biosynthesis }\end{array}$ & Reductase \\
\hline 3 & P63261 & 49.1 & $\begin{array}{l}\text { Actin, cytoplasmic } 2 \\
\text { (Gamma-actin) }\end{array}$ & Cell structure & $\begin{array}{l}\text { Actin and actin } \\
\text { related protein }\end{array}$ \\
\hline 4 & O95445 & 32.4 & $\begin{array}{l}\text { Apolipoprotein M } \\
\text { (Apo-M) }\end{array}$ & Lipid transport & Plasma protein \\
\hline 5 & P06727 & 67.7 & Apolipoprotein A-IV & $\begin{array}{l}\text { Lipid and fatty acid } \\
\text { transport }\end{array}$ & Transporter \\
\hline 6 & P02775 & 41.4 & Platelet basic protein & $\begin{array}{l}\text { Pyrimidine } \\
\text { metabolism }\end{array}$ & Phosphorylase \\
\hline 7 & P02647 & 85.8 & Apolipoprotein A-I & $\begin{array}{l}\text { Lipid and fatty acid } \\
\text { transport }\end{array}$ & Transporter \\
\hline 8 & P01023 & 39.8 & $\begin{array}{l}\text { Alpha-2- } \\
\text { macroglobulin }\end{array}$ & $\begin{array}{l}\text { Developmental } \\
\text { processes }\end{array}$ & $\begin{array}{l}\text { Serine/threonine } \\
\text { kinase }\end{array}$ \\
\hline 9 & P02787 & 58.9 & Serotransferrin & $\begin{array}{l}\text { Amino acid } \\
\text { biosynthesis }\end{array}$ & Synthase \\
\hline 10 & P04275 & 11.3 & von Willebrand factor & Cell adhesion & $\begin{array}{l}\text { Extracellular matrix } \\
\text { glycoprotein }\end{array}$ \\
\hline 11 & P02671 & 35.2 & Fibrinogen alpha chain & $\begin{array}{l}\text { Cell proliferation } \\
\text { and differentiation }\end{array}$ & $\begin{array}{l}\text { Extracellular matrix } \\
\text { glycoprotein }\end{array}$ \\
\hline 12 & P01024 & 29.6 & Complement C3 & $\begin{array}{l}\text { Nerve-nerve } \\
\text { synaptic } \\
\text { transmission }\end{array}$ & Glutamate receptor \\
\hline 13 & P98160 & 5.1 & $\begin{array}{l}\text { Heparan sulfate } \\
\text { proteoglycan }\end{array}$ & Extracellular matrix & $\begin{array}{l}\text { Cell adhesion } \\
\text { mediated signal }\end{array}$ \\
\hline 14 & P51884 & 33.4 & Lumican & Receptor & $\begin{array}{l}\text { Cell } \\
\text { adhesion-mediated } \\
\text { signaling }\end{array}$ \\
\hline 15 & P04114 & 41.5 & Apolipoprotein B-100 & $\begin{array}{l}\text { Lipid and fatty acid } \\
\text { transport }\end{array}$ & $\begin{array}{l}\text { Component of } \\
\text { serum lipoproteins }\end{array}$ \\
\hline 16 & Q8WZ42 & 9.5 & $\begin{array}{l}\text { Titin (EC 2.7.11.1) } \\
\text { (Connectin) }\end{array}$ & Muscle contraction & $\begin{array}{l}\text { Actin binding } \\
\text { cytoskeletal protein }\end{array}$ \\
\hline 17 & P08519 & 11 & Apolipoprotein(a) & $\begin{array}{l}\text { Cell proliferation } \\
\text { and differentiation }\end{array}$ & Peptide hormone \\
\hline 18 & P43652 & 47.7 & Afamin & Transport & $\begin{array}{l}\text { Other } \\
\text { transfer/carrier } \\
\text { protein }\end{array}$ \\
\hline 19 & P06396 & 54.9 & Gelsolin & Cell structure & $\begin{array}{l}\text { Nonmotor actin } \\
\text { binding protein }\end{array}$ \\
\hline 20 & P02749 & 54.2 & Beta-2-glycoprotein 1 & $\begin{array}{l}\text { Amino acid } \\
\text { metabolism }\end{array}$ & Transaminase \\
\hline 21 & Q9NYC9 & 4.8 & Dynein heavy chain 9 & $\begin{array}{l}\text { Force generating } \\
\text { protein }\end{array}$ & ATPase activity \\
\hline 22 & P32119 & 4 & Peroxiredoxin-2 & Redox regulation & $\begin{array}{l}\text { Eliminating } \\
\text { peroxides }\end{array}$ \\
\hline
\end{tabular}

$13.3 \%$ proteins identified in the DS sample correspond to proteins found in the Alzheimer disease-amyloid secretase and Alzheimer disease-presenilin pathways illustrated in Figure 5.This indicates that these pathways should be more closely studied in conjunction with DS. More than the $40 \%$ of the protein we identified in DS samples correspond to proteins in the Integrin signalling pathway. This might be due to the fact that cell adhesion molecules and extra cellular matrix protein represent $13 \%$ and $18 \%$ of the total proteins identified, respectively as illustrated in Figure 4. 


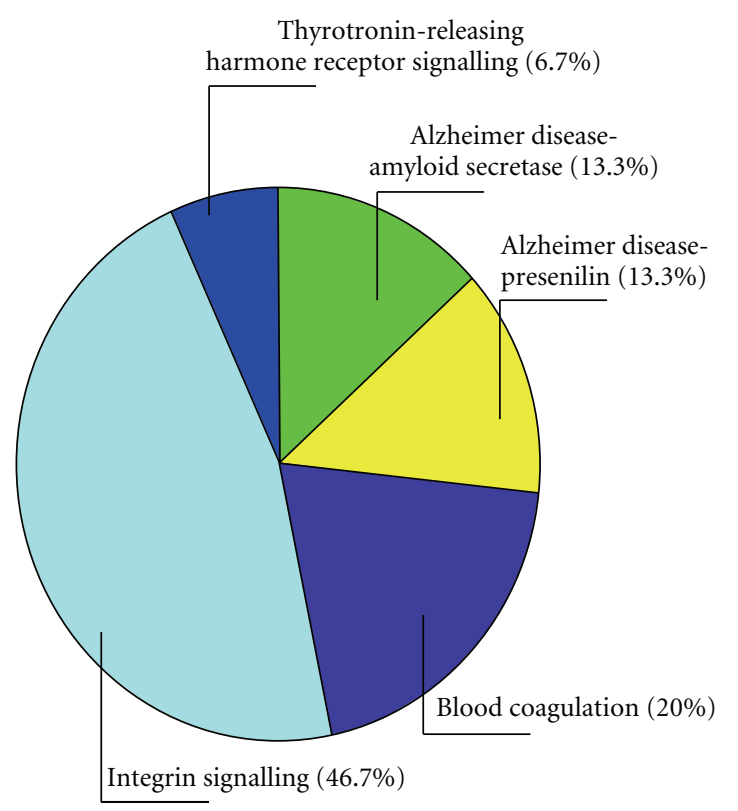

FIGURE 5: PANTHER analysis for pathway. In total, 28 proteins were identified as elevated and 22 proteins were under expressed. Shown above is the different signaling pathways hits by these protein.

\section{Discussion}

Quantitation of serum or plasma proteins via iTRAQ analysis has recently been suggested to be suitable for the detection of biomarkers, as the method is highly reproducible, with little run-to-run variation. This aspect, which is optimal to embark on such a "fishing-expedition", is actually quite surprising, granted the large number of individual steps in the work-flow. This conclusion was, however, derived at after a lengthy comparison involving three pools of case and control samples, as well as a number of individual samples, where a coefficient of variation of $11.7 \%$ was noted [21].

In a preliminary proof-of-principle experiment, we have now assessed whether this method could be suitable for the detection of biomarkers useful for DS screening. From our small-scale preliminary evaluation we identified over 200 proteins whose concentration was altered in the plasma of pregnancies with a DS fetus when compared to those with euploid fetuses.

It is of interest that $\beta \mathrm{hCG}$ is detected in the pool of proteins found to be elevated. This glycoprotein, which is produced early in pregnancy by the developing embryo and subsequently by the syncytiotrophoblast, forms the backbone of 1 st and 2nd trimester screening strategies. In the 1st trimester, pregnancies at-risk of carrying a fetus affected by DS are identified on the basis of an almost 2 fold MoM (Multiples of the Median) elevation in $\beta$ hCG. The presence of this important screening marker in our pool of elevated plasma proteins suggests that the strategy we have chosen for the identification of new biomarkers is functional and worthy of further pursuit.

In this context it is worth noting that this marker was not detected in two previous studies $[9,11]$ using proteomic technologies for the identification of protein markers for DS in maternal plasma or serum. This could be due to limitations in detection sensitivity of the 2D gel approach these studies had used.

That our assay is indeed detecting proteins of placental origin is illustrated by presence of pregnancy zone protein which is a glycoprotein and a proteinase inhibitor which derive its importance in pregnancy by playing potential role in preventing the attack from maternal immune system on the developing fetus which can be seen as foreign allograft [22].This protein was amongst our list of up-regulated proteins, which is similar to alpha 2-macroglobulin, is quantitatively the most important pregnancy-associated plasma protein.

Amongst the pool of up-regulated proteins were serum amyloid P-component and amyloid beta A4, which is encouraging as members of this family have found to be elevated in previous studies on pregnancies with DS fetuses, which may be a reflection of an altered gene expression pattern associated with DS-related dementia. It is also important to note that the amyloid precursor protein (APP) gene is located in DS region of chromosome 21. Teller and colleagues have shown that a relatively minor from of amyloid beta protein was present in the brain of DS affected pregnancy as early as in late 2nd trimester [23].

Elevations in a number of inflammatory molecules, most of which are probably of maternal origin, may be a reflection of the elevated release of placental debris which has been suggested to occur in pregnancies with DS fetuses. Phosphatidylinositol-glycan is expressed in the placental tissue [24], also involved in many cellular process and plays important role in several signal transduction pathways.

Of the down-regulated proteins like actin, gelsolin, heparan sulfate proteoglycan [25], and fibrinogen alpha chain, it is noteworthy that all these protein are involved in cell adhesion, extracellular matrix, cell structure or muscle contraction, since DS fetuses are known to exhibit connective tissue abnormalities [26], the most pronounced of which is the increased neck fold (nuchal translucency). Since adult DS patients are prone to skeletal muscle deficiency, our finding concerning reduced titin plasma levels is intriguing, as this very large protein plays an important role in muscle contraction. In one of recent study Du and colleague [27] have shown trophoblast expression of titin in first trimester placentae.

Only a limited number of studies have attempted to use proteomic approaches for the discovery of new biomarkers for pregnancies at-risk of carrying a fetus with DS, two of these used 2-DE approaches [9, 11], while a further used a SELDI method [10]. Study of the former studies that by Nagalla and colleagues is the largest, having examined serum samples from 56 pregnant women. This study used samples collected in both the 1st and 2nd trimester of pregnancy, which were recruited as part of the NIH funded FASTER study, and largely made use of the fluorescent 2D-DIGE process. In their study, 18 proteins were found to be elevated in 1st trimester samples, which included members of the apoliprotein family, clusterin and proteins involved in skeletal development (tetranectin). The study by 
Kolialexi and colleagues [11] used traditional 2DE stained with Coomassie blue on 20 maternal plasma samples (8 cases, 12 controls, 16-18 weeks of pregnancy), by which means 8 candidate proteins were detected. Elevations were noted for apoliprotein $\mathrm{E}$ and serum amyloid P-component. In contrast to the study by Nagalla et al. [9] a down regulation for clusterin was noted.

In the study by Busch and colleagues [10] using a SELDI approach, traces were noted which differed between DS cases and controls. However, no attempt was made to discern what proteins were responsible for these altered patterns, nor was any detailed description provided of how they could be reproduced.

Other than common elevation in serum amyloid and complement component families, little commonality exists between our study and these studies. This may be due to a number of factors including, limited study size, time of sampling collection, sample processing and storage, as well as use of very different technical approaches. In our follow-up studies we would like to validate these putative biomarkers using immunoblot and Enzyme linked immunosorbent assay (ELISA). More recently Selected Reaction Monitoring (SRM) [28] has evolved as a method of choice for validation of biomarkers using mass spectroscopy.

The increasing popularity of the iTRAQ approach due to its reproducibility and robustness, including studies for cancer or inflammatory autoimmune disorder specific biomarkers suggests that it will become the method of choice for future studies, until it is surpassed by a new technical development. As pregnancy represents a unique constellation, whereby a foreign being is supported and nourished by the host, it may serve as an ideal model for proteomic analyses, as any unique markers should ideally disappear post delivery. Furthermore, as very few specific biomarkers exist to assist with the screening of a number of pregnancy-related disorders, especially preeclampsia or preterm labour, it is likely that this will become the focus of considerable research attention in the near future.

\section{Conclusion}

In this report we conclude that isobaric labelling technique is a suitable approach for the quantitative detection of new screening biomarkers in the plasma of pregnancies with a DS fetus compared to those with euploid fetuses. In this preliminary proof-of-principle study, we were able to detect quantitatively under- or over-expressed proteins. In the future additional studies, using larger sample sizes will be required to identify a panel of biomarkers which can be used in screening for DS pregnancies.

\section{Acknowledgment}

The authors thank Vivian Kiefer for her technical assistance and Professor E. Palmer and Dr. D. Huang for the proofreading of the manuscript. This study was supported by PREGENESYS (ref.no. 37244), Sixth Frame Work (FP6) grant.

\section{References}

[1] K. A. Eddleman, F. D. Malone, L. Sullivan, et al., "Pregnancy loss rates after midtrimester amniocentesis," Obstetrics and Gynecology, vol. 108, no. 5, pp. 1067-1072, 2006.

[2] E. Guetta, M. J. Simchen, K. Mammon-Daviko, et al., "Analysis of fetal blood cells in the maternal circulation: challenges, ongoing efforts, and potential solutions," Stem Cells and Development, vol. 13, no. 1, pp. 93-99, 2004.

[3] Y. M. D. Lo, "Recent advances in fetal nucleic acids in maternal plasma," Journal of Histochemistry and Cytochemistry, vol. 53, no. 3, pp. 293-296, 2005.

[4] R. D. Wilson, "Cell-free fetal DNA in the maternal circulation and its future uses in obstetrics," Journal of Obstetrics and Gynaecology Canada, vol. 27, no. 1, pp. 54-62, 2005.

[5] K. Spencer, "Aneuploidy screening in the first trimester," American Journal of Medical Genetics, Part C: Seminars in Medical Genetics, vol. 145, no. 1, pp. 18-32, 2007.

[6] R. Ricco, A. M. Dalena, T. Valente, et al., "Quantitative study of placental villi in trisomy by analytical morphometry," Analytical and Quantitative Cytology and Histology, vol. 31, no. 1, pp. 41-48, 2009.

[7] S.-J. Park, W.-G. Yoon, J.-S. Song, et al., "Proteome analysis of human amnion and amniotic fluid by two-dimensional electrophoresis and matrix-assisted laser desorption/ionization time-of-flight mass spectrometry," Proteomics, vol. 6, no. 1, pp. 349-363, 2006.

[8] G. T. Tsangaris, A. Kolialexi, P. M. Karamessinis, et al., "The normal human amniotic fluid supernatant proteome," In Vivo, vol. 20, no. 4, pp. 479-490, 2006.

[9] S. R. Nagalla, J. A. Canick, T. Jacob, et al., "Proteomic analysis of maternal serum in down syndrome: identification of novel protein biomarkers," Journal of Proteome Research, vol. 6, no. 4, pp. 1245-1257, 2007.

[10] A. Busch, S. Michel, C. Hoppe, D. Driesch, U. Claussen, and F. Von Eggeling, "Proteome analysis of maternal serum samples for trisomy 21 pregnancies using proteinchip arrays and bioinformatics," Journal of Histochemistry and Cytochemistry, vol. 53, no. 3, pp. 341-343, 2005.

[11] A. Kolialexi, A. Mavrou, G. Spyrou, and G. T. Tsangaris, "Mass spectrometry-based proteomics in reproductive medicine," Mass Spectrometry Reviews, vol. 27, no. 6, pp. 624-634, 2008.

[12] N. L. Anderson and N. G. Anderson, "The human plasma proteome: history, character, and diagnostic prospects," Molecular \& Cellular Proteomics, vol. 1, no. 11, pp. 845-867, 2002.

[13] P. L. Ross, Y. N. Huang, J. N. Marchese, et al., "Multiplexed protein quantitation in Saccharomyces cerevisiae using aminereactive isobaric tagging reagents," Molecular \& Cellular Proteomics, vol. 3, no. 12, pp. 1154-1169, 2004.

[14] P. G. Righetti, E. Boschetti, L. Lomas, and A. Citterio, "Protein equalizer technology : the quest for a "democratic proteome"," Proteomics, vol. 6, no. 14, pp. 3980-3992, 2006.

[15] R. D. Unwin, A. Pierce, R. B. Watson, D. W. Sternberg, and A. D. Whetton, "Quantitative proteomic analysis using isobaric protein tags enables rapid comparison of changes in transcript and protein levels in transformed cells," Molecular \& Cellular Proteomics, vol. 4, no. 7, pp. 924-935, 2005.

[16] J. E. Elias and S. P. Gygi, "Target-decoy search strategy for increased confidence in large-scale protein identifications by mass spectrometry," Nature Methods, vol. 4, no. 3, pp. 207214, 2007.

[17] I. V. Shilov, S. L. Seymourt, A. A. Patel, et al., "The paragon algorithm, a next generation search engine that uses sequence temperature values sequence temperature values and feature 
probabilities to identify peptides from tandem mass spectra," Molecular \& Cellular Proteomics, vol. 6, no. 9, pp. 1638-1655, 2007.

[18] H. Mi, N. Guo, A. Kejariwal, and P. D. Thomas, "PANTHER version 6: protein sequence and function evolution data with expanded representation of biological pathways," Nucleic Acids Research, vol. 35, database issue, pp. D247-D252, 2007.

[19] A. Glen, C. S. Gan, F. C. Hamdy, et al., “iTRAQ-facilitated proteomic analysis of human prostate cancer cells identifies proteins associated with progression," Journal of Proteome Research, vol. 7, no. 3, pp. 897-907, 2008.

[20] C. S. Gan, P. K. Chong, T. K. Pham, and P. C. Wright, "Technical, experimental, and biological variations in isobaric tags for relative and absolute quantitation (iTRAQ)," Journal of Proteome Research, vol. 6, no. 2, pp. 821-827, 2007.

[21] X. Song, J. Bandow, and J. Sherman, "iTRAQ experimental design for plasma biomarker discovery," Journal of Proteomic Research, vol. 7, no. 7, pp. 2952-2958, 2008.

[22] E. L. Skornicka, N. Kiyatkina, M. C. Weber, M. L. Tykocinski, and P. H. Koo, "Pregnancy zone protein is a carrier and modulator of placental protein-14 in T-cell growth and cytokine production," Cellular Immunology, vol. 232, no. 1-2, pp. 144-156, 2004.

[23] J. K. Teller, C. Russo, L. M. DeBusk, et al., "Presence of soluble amyloid $\beta$-peptide precedes amyloid plaque formation in Down's syndrome," Nature Medicine, vol. 2, no. 1, pp. 9395, 1996.

[24] A. M. Vinggaard, J. J. Provost, J. H. Exton, and H. S. Hansen, "Arf and RhoA regulate both the cytosolic and the membrane-bound phospholipase D from human placenta," Cellular Signalling, vol. 9, no. 2, pp. 189-196, 1997.

[25] R. Timpl and J. C. Brown, "Supramolecular assembly of basement membranes," BioEssays, vol. 18, no. 2, pp. 123-132, 1996.

[26] F. K. Wiseman, "Down syndrome-recent progress and future prospects," Human Molecular Genetics, vol. 18, no. R1, pp. R75-R83, 2009.

[27] M.-R. Du, W.-H. Zhou, F.-T. Yan, et al., "Cyclosporine A induces titin expression via MAPK/ERK signalling and improves proliferative and invasive potential of human trophoblast cells," Human Reproduction, vol. 22, no. 9, pp. 2528 2537, 2007.

[28] V. Lange, "Selected reaction monitoring for quantitative proteomics: a tutorial," Molecular Systems Biology, vol. 4, p. 222, 2008 . 

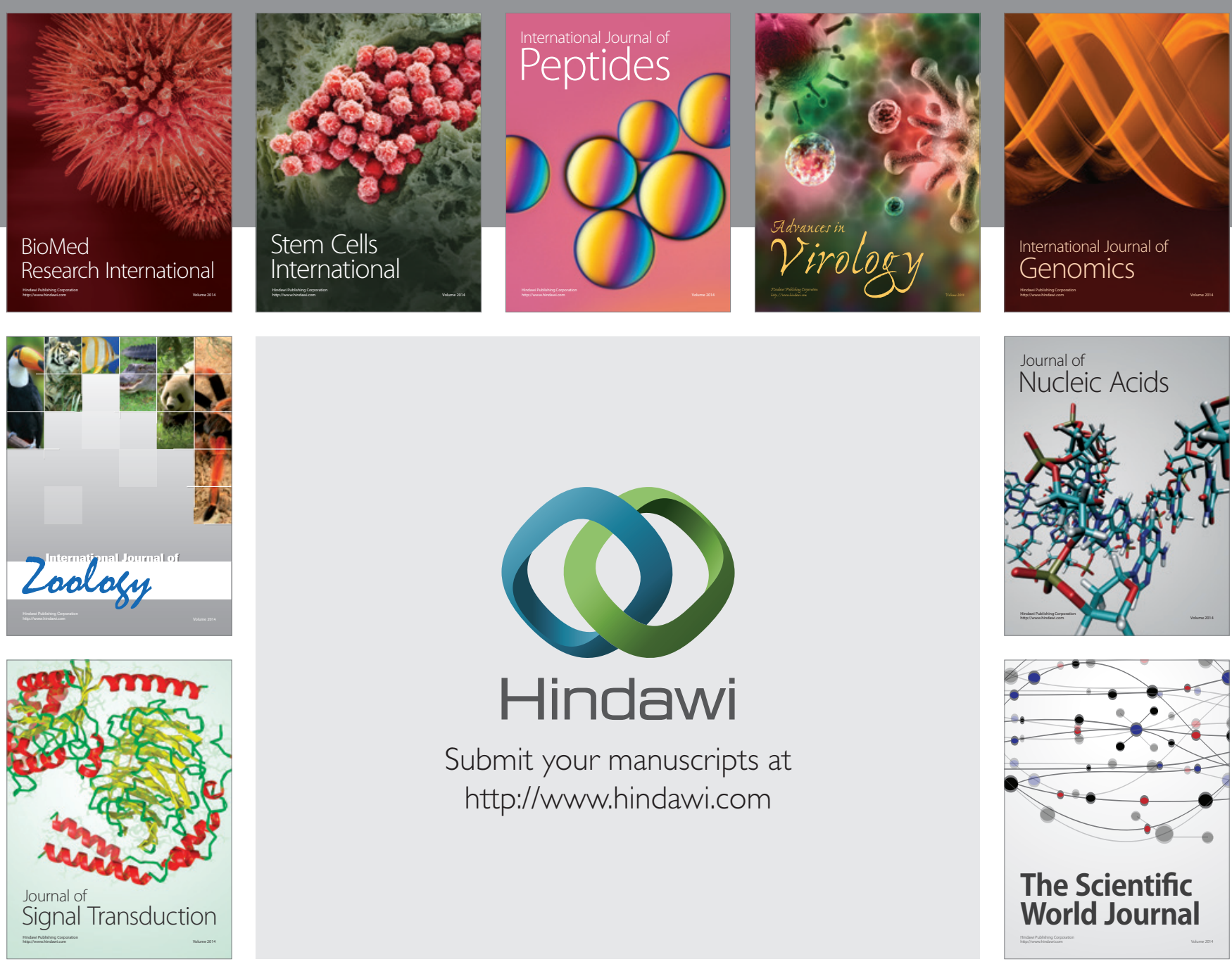

Submit your manuscripts at

http://www.hindawi.com
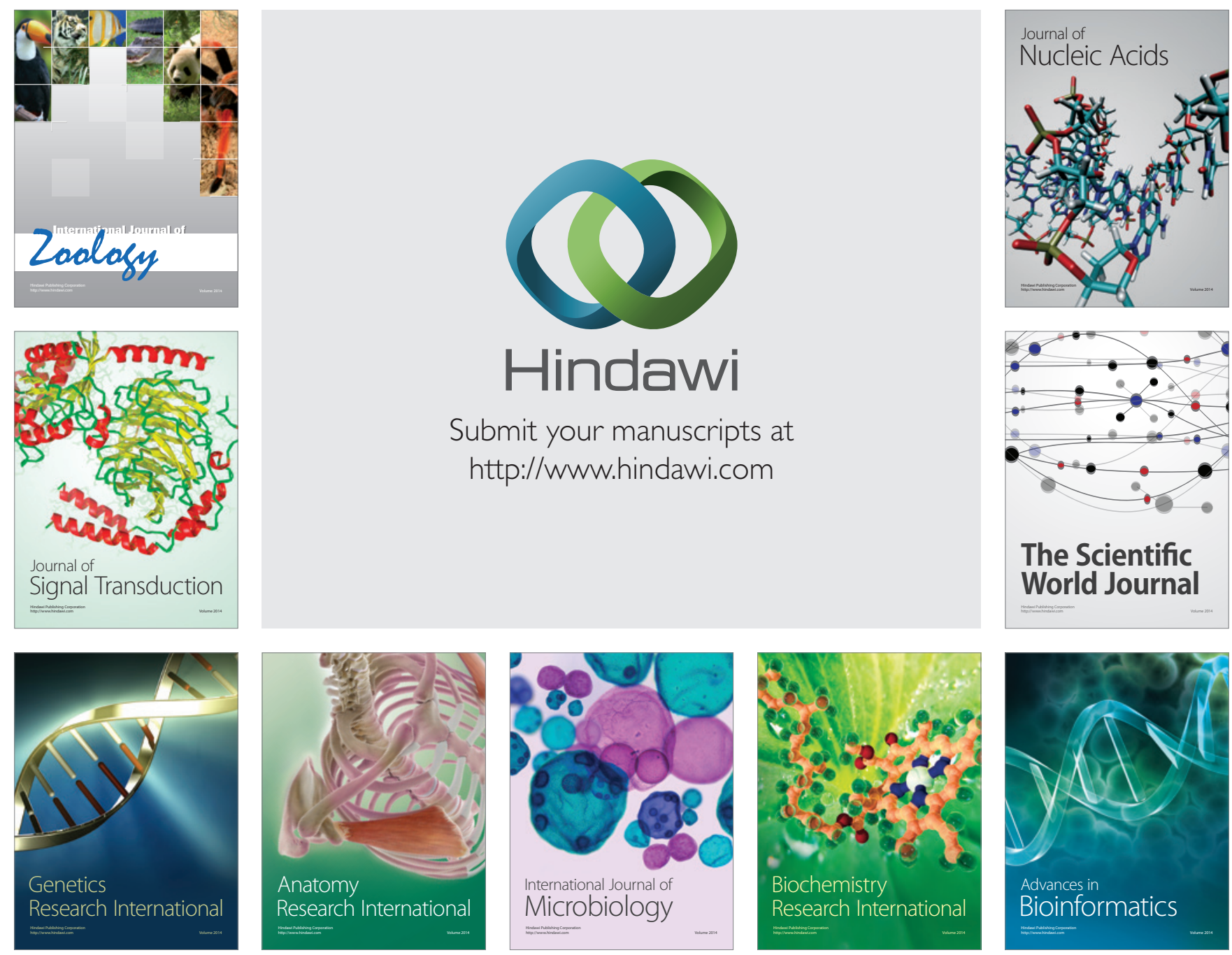

The Scientific World Journal
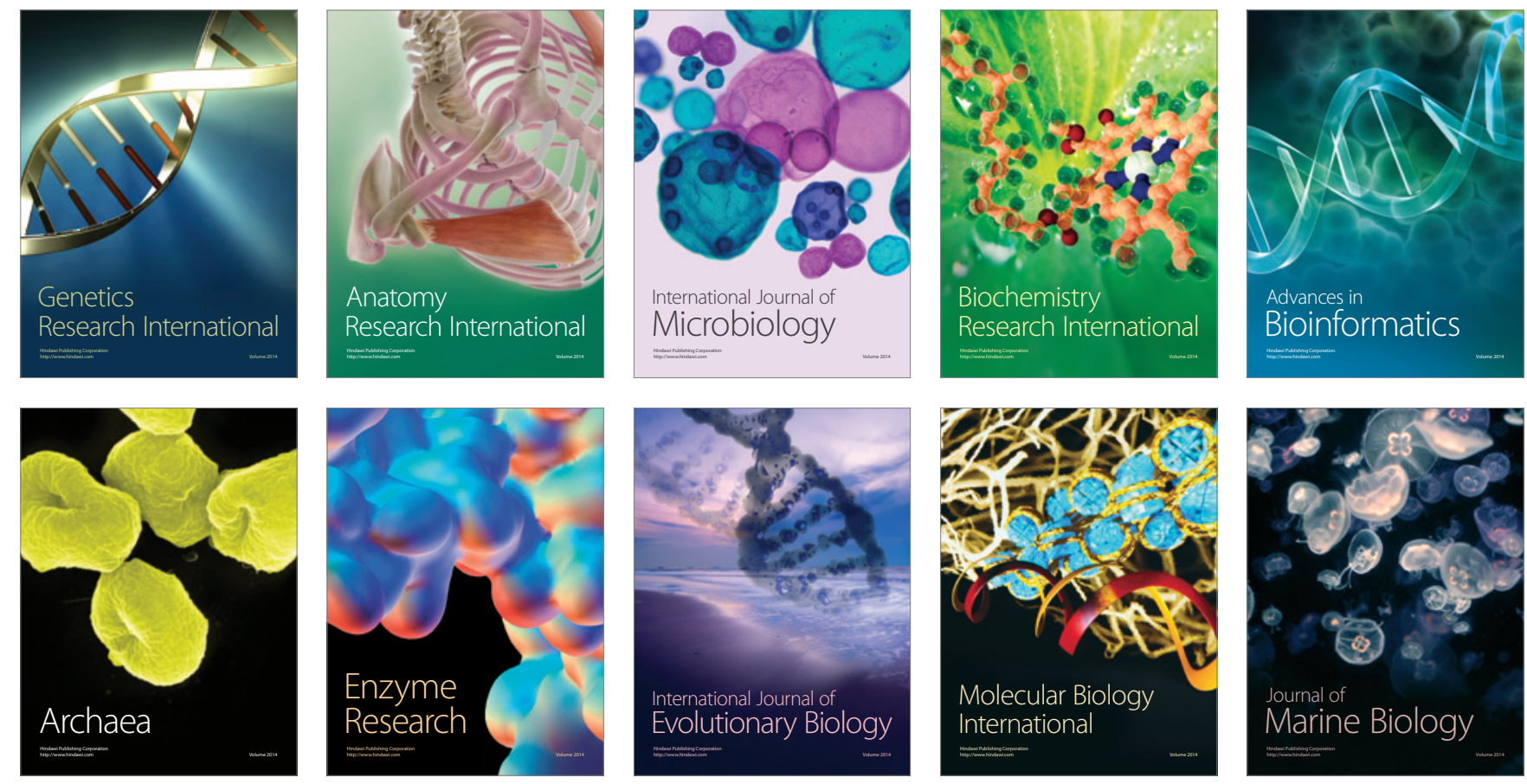